\title{
Information management through human resources spectacles
}

\author{
Neil Duffy \\ Graduate School of Business Administration, University of the Witwatersrand, P.O. Box 98, Wits 2050, Republic of South Africa
}

Received 30 April 1991, accepted 24 September 1991

\begin{abstract}
The purpose with this article is to highlight the similarities of, and mutual dependence between, information management and human resource management. Information pervades almost everything we do. The information resource itself comprises applications, tools, people, organization, software, hardware and data. Many of the issues that drive information systems today have strong human resources (HR) connotations: organizational learning, IS's role, contribution and alignment in the organization, end-user computing, IS implementation, change and organization design. Both IS and HR manage a key resource, require a strategic vision, are important components of the strategic plan, have similar components and are experiencing changing and increasingly important roles in their organizations. IS itself has become increasingly high touch over the years and as such needs to draw more and more on HR skills and support. In future the bottom line will depend on strength in both HR and IS and the ability of management to derive synergy from them.
\end{abstract}

Die doel met hierdie artikel is om die gelyksoortigheid en interafhanklikheid van inligtingsbestuur en die bestuur van die menslike hulpbron uit te lig. Inligting syfer deur na amper alles wat ons doen. Die inligtingshulpbron bestaan uit rekenaartoepassings, metodiek en hulpmiddele, mense, organisasie, programmatuur, apparatuur en data. Baie van die dryflcragte van inligtingstelsels het sterk menslike konnotasies, byvoorbeeld die leerproses van organisasies, inligtingstelsels se rol, bydrae en aanpassing in organisasies, die toepassing van rekenaars deur gebruikers, die implementering van inligtingstelsels, verandering en die ontwerp van organisasies. Beide inligtingsbestuur en menslike hulpbronbestuur word toegespits op 'n sleutelhulpbron, vereis visie, is belangrike komponente van die strategiese plan, bestaan uit soortgelyke komponente, en beleef veranderende en belangrike rolle binne organisasies. Inligtingstelsels self het oor die jare in 'n toenemende mate 'high touch' geword en sodoende groter menslike bekwaamhede vereis. In die toekoms sal winsgewendheid van die doeltreffendheid van beide die menslike hulpbron en inligtingsbestuur afhang, sowel as die vermoè van die topbestuur om wisselwerking tussen hulle te bewerkstellig.

'I tell you, sir, the only safeguard of order and discipline in the modern world is a standardized worker with interchangeable parts. That would solve the entire problem of management' - Jean Giraudoux.

\section{Introduction}

The world has become an increasingly complex, fast-changing and unstable place. At an international level regional conflicts, terrorism, superpower summits, starvation in many countries, Third World debts, doubts about the United States' economy and the consequences of this for the dollar and world stock markets, are a few of the crosscurrents that buffet the citizens of this globe. At a national (South African) level we have, as do all countries, our own problems: political unrest, militant trade unionism, high inflation, disinvestment and sanctions pressures, and an economy attempting to recover from all this.

Against this turbulent background we find burgeoning technology, particularly information technology. Supercomputers, mainframes, minicomputers and microcomputers become steadily more powerful using very large scale integration (VLSI) and 32-bit chips with gallium arsenide, transputers and even bioelectronics as possible future developments. Data communications have long since incorporated optical fibre, videotex, local and wide area networks (LANs and WANs), micro to mainframe links and distributed processing and have entered the satellite age. Communications are moving towards integrated voice, data and image transmission with integrated services digital networks (ISDNs) and voice recognition. Data bases are including optical disks and benefitting from more effective and sophisticated data base management systems. Fourth generation software has arrived, fifth generation software is emerging and the sixth generation is being talked about. Artificial intelligence has emerged from the research laboratories in the form of expert systems. Packaged software at the microcomputer level has become a flood.

All of these developments have, and will continue to have, dramatic effects on society as a whole and management in particular. In many industries and professions information systems are an integral part of strategic management, including strategic marketing and competitive strategy, and are absorbing huge proportions of available resources. Senior managements grapple with issues that seem to become more challenging and information-related issues loom larger by the year.

The purpose of this article is to highlight the similarities of, and mutual dependence between, information management and human resource management. It will outline how the field of information management is developing in the face of all this. Some discussion of underlying concepts will be necessary but will be kept to a minimum. Having considered information management, the information resource and the issues that surround them, we will trace the common threads with the closely related discipline of human resource management. It can be argued that, in many respects, information resource management (IRM) and human resource management (HRM) face common issues and intertwined destinies. The article ends with a review of what HRM can do for IRM, to help both survive and prosper in an increasingly turbulent world.

\section{Management of Information}

Information is everywhere

Information pervades almost everything we do. In a 
business context, the following examples illustrate the point:

- A machine operator works according to information in the form of written or verbal instructions and from information stored in his head as operating skills and experience.

- A clerk processes invoices according to information in a procedure manual or from information stored in her head as know-how.

-A sales manager monitors the performance of his sales people from information in the form of sales reports and call reports.

- A board of directors takes decisions based on information contained in board papers and personal information called experience or knowledge acquired elsewhere.

- A bank manager decides whether or not to advance funds to a company based on information she has about that company.

-A potential customer decides whether or not to buy a product based on information she has about the produch, the organization, competitive products and, perhaps, about the salesperson.

In these examples information has been called various things such as experience, know-how, knowledge and operating skills. In all cases, however, information intemal or external to the person concerned drives an activity or a decision. The examples listed above show that all meaningful business activities or decisions are based upon information in one form or another.

\section{Basic information systems concepts}

Structured ways of providing information can be called information systems (IS) and the high technology, such as computers, upon which many information systems are based, is referred to as information technology (IT).

One basic terminological distinction needs to be made at the outset: the distinction between information systems, management information systems, transaction processing and decision support systems.

In any organization certain fundamental processes and accompanying data flows occur. For example, in a manufacturing organization the fundamental processes are the acquisition and processing of materials and the distribution of the finished products. In order to carry out these processes a variety of documents must be produced and distributed. These include goods received notes, stores requisitions, clock cards, time sheets, payslips, invoices and statements - to name a few.

Without this document flow no business process could take place. The initiation, processing and distribution of these fundamental documents is what is referred to by the term transaction processing. Traditionally transaction processing has been carried out on a manual basis, where it has received the attention of organization and works $(\mathrm{O}$ and W) people, or by means of data processing equipment, in which case it is called data processing.

Planning, organising and controlling the resources and transaction processing of an organization is a function of management. To do this, managers require information and the systems that provide this information are called information systems or management information systems (MIS). The latter two terms are used synonymously in much of the literature. To be more specific, however, information systems should be used to denote both MIS and transaction processing: that is, as an encompassing term (IS $=$ MIS plus transaction processing). Finally, decision support systems (DSS) relates to the use of computer-based information systems to support decision making. DSS can therefore be viewed as a subset of MIS.

Information management, the topic of this article, is the planning, organising, developing and controlling of the information and data in an organization at both corporate and individual levels and of the people hardware, software and systems that produce the information and data. As such it is indistinguishable from most definitions of information resource management (IRM) and the two will be treated as synonyms.

In defining IS or MIS, one can describe their purpose (what they are intended to do), their physical elements (of what they are composed) or how they function (what they do). Appreciation of this fact alone can reduce confusion resulting from the variety of definitions.

'In essence an information system is a collection of people, procedures, a base of data and (sometimes) hardware and software, that collects, processes, stores and communicates data for processing transactions at operational level and information to support management decision making or to constitute part of the product or service' (Duffy \& Assad, 1989: 6).

A number of important implications arise from this definition:

- Information systems have always existed in organizations and always will.

- Information systems support both the basic operations of an organization and its management.

- Information can form an essential part of an organisation's product or service; indeed it can be the whole product or service.

- A computer is not always an essential element of an information system. This need is determined by the amount of data or information to be processed and the complexity or speed of processing required.

-A distinction is drawn between data for transactionprocessing purposes and information for decision-making purposes.

- Attention is drawn to the concepts underlying information systems namely, people, management, information, systems and organizations.

\section{Information resource}

So far we have talked about information management in an organization. It is time to explain what is meant by 'the information resource'. In no particular order the components of the information resource are:

\section{Applications}

These are the information systems themselves that drive the 
transaction processing of an organization, support management decision making, automate the office, provide expertise and deliver competitive advantage.

\section{Tools}

The methodologies and other technological tools which are used by information systems people and end users to build information systems. They include development methodologies and automated system building aids called CASE (Computer-Aided Software Engineering).

\section{People}

Information systems are built by people for their own or other people's use. The Information System Executive (Chief Information Officer, Information Systems Manager) and his team of IS professionals, make up the IS component while users, management and non-IS support personnel comprise the balance.

\section{Organization}

The organization structures within which the IS and other people are located. This includes not only departmental or divisional groupings but also committees, teams and task groups.

\section{Software}

The operating systems, packages, fourth and fifth generation languages and expert systems shells used to produce the specific IS applications for the organization.

\section{Hardware}

The mainframes, minicomputers and personal computers upon which the applications are developed and run. Included in this would be the data communications networks that link computers and workstations.

\section{Data}

The corporate and individual data required for the organisation to operate. These data are usually organised in data bases which are established, run and maintained by DBMS's (Data Base Management Systems).

\section{Issues that drive us}

The issues that drive information systems today are many, diverse, complicated and fast-moving. Let us look at a few that are of particular interest to HR practitioners.

\section{Organizational learning}

The impact of IS will extend into most nooks and crannies in an organization. In many organizations it is bound up in the corporate and competitive strategies and it is changing many traditional functional areas. In order to recognize relevant IT, pilot it, and successfully disperse it throughout the organization, is going to require a mammoth educational effort over the next few years. This is necessary in three distinct areas: management, end users and IS personnel.

\section{IS's role, contribution and alignment}

The emergence of IS from the backroom that we have been describing has overtumed conventional ideas about reporting lines, organizational placement and IS budgets in many organizations. These effects need to be examined by top management.

As organizations grow larger, with more subsidiaries and more divisions, it becomes increasingly difficult to decide whether to centralize or decentralize computer hardware, software and people and where to locate them in the organisation structure. Indeed how should one manage IT or information as a strategic corporate resource - often called 'information resource management'? The effects of information systems on organizations and vice versa are not well understood.

\section{End-user computing}

More user-friendly software and more cost effective hardware are leading to the growth of end-user computing - the development of information systems by end users. The steadily increasing computer literacy of end users will no doubt add impetus to this trend. There are two aspects of end-user computing that require special consideration, namely fourth generation languages and information centres.

Growing application development backlogs, unmaintainable systems, the shortage and cost of DP professionals, outdated and overlong information definition techniques and the increasing strategic importance of information systems in many organizations has led to the emergence of fourth and fifth generation languages and automated system building software (CASE). The objectives of these tools include minimal training requirements even for people without programming experience, the ability to be used by such people and a reduction in system development time by an order of magnitude. There is little doubt that their impact on information processing, users and management will be farreaching.

Information centres are relatively new organizational units falling inside or outside DP that are designed to:

- Provide a source of expert advice to users as to what information technology is best in the circumstances and what suppliers should be considered.

- Assist users to do their own application development within a managed framework that ensures compliance with necessary organizational standards but otherwise imposes minimal control on them.

- Train the end users. This involves both initial training in the use of the information tool and subsequent handholding.

Apart from the issue of making information centres effective, some organizations report an explosion of demand from end users thus causing a whole new set of problems.

\section{Information systems implementation}

An appreciable number of IS practitioners maintain that implementing IS and IT is the most difficult part of the whole process. Issues such as the following arise during the implementation phase:

- How can organizational leaming be facilitated in this particular situation? 
- What organization design, such as information centres, will aid IS implementation?

- What organizational factors will affect the adoption of IS?

- IS can increase control or work freedom in an organisation. What balance do we wish to maintain?

- What are the implications of having our people work from home via terminals or micros (the so-called 'electronic cottage' or 'electronic workplace')?

- How can we improve our management of change to accommodate increasingly rapid change? How fast can we change if we have to?

- What are the likely impacts of proposed IS implementation on individuals, work processes, organization culture and communications?

- Are we going to encounter resistance from staff and, if so, how do we handle it?

The question of potential unemployment becomes a crucial issue especially when the use of robots has been expanding rapidly in countries such as Japan and the United States. The social implications of such a development in South Africa are far-reaching to say the least. On the other hand there is the vast potential of information technology for improving jobs (Canning, 1983).

\section{Change}

One important reason for the perceived difficulty of implementing IS is that they change from being technicallyoriented to being people-oriented once implementation commences and many IS managers are not noted for their proficiency in predominantly human behavioural areas. Indeed this does not apply to IS managers only.

Implementing IS can transform the quality of life, the job environment, the job itself, required job skills, social interactions, power bases, expectations and motivation of all the people involved in the development. It is a form of technological change with all that this implies. If the full benefits of the systems are to be realized and dysfunctional effects from the IS are to be minimized, they need to be anticipated and planned for. In short change should be part of the process at both IS planning and project planning stages.

\section{Organization design}

It has already been mentioned that the question of organization structure should be explicitly considered as part of the strategic planning process as an obsolete structure may be an insurmountable problem in an already difficult process of trying to achieve organizational objectives. The organization structure should not be left to catch up, as has so often been done in the past. On the positive side restructuring can facilitate organizational change by realigning tasks, responsibilities and relationships; but, on the negative side, many managers seem to respond automatically to any perceived problem by reorganising.

The traditional mainstream activities of data processing organizations have been systems, programming and operations. The organizational problem is becoming one of where to fit manual systems (organization and work study), operations research, office automation, end-user computing (including information centres), expert systems, computer integrated manufacturing, printing (with the arrival of desktop publishing), micrographics, library activities, mailing (with electronic mail on the increase), data communication, IS planning, and technological innovation.

Organization structuring of IS is further complicated by:

- the fact that each design must be tailored to a specific organization;

- the shift of control away from the IS department precipitated by end-user computing, office automation, increased user access to corporate databases, distributed processing, and other factors;

- the centralization/decentralization dilemma;

- the dynamics of organizations which means that an organizational design that is appropriate at one stage of growth is almost certainly inappropriate at the next stage; and

- the fact that organizations often comprise multiple strategic business units, many of which will be at different stages of growth and technological maturity and have different information needs.

Perhaps the only reasonably certain principle is that organizational needs and not technological considerations should drive the organization design.

\section{IS Executive}

Defining the roles of people involved with IS has never been easy. In many cases we have been aiming at a moving target. As soon as the skills required by a systems analyst or an IS manager have seemed to be emerging we have found that the roles have changed in the meantime and that we are searching for new skill requirements.

Some job titles have remained the same but the roles behind those titles have been changing in response to the march of the technology. Top management, end users, business analysts, systems analysts, programmers, operators, 0 and $\mathrm{W}$ (Organization and Works) analysts, librarians, systems programmers, data communications specialists and database administrators are all familiar job titles but the perceptions of what they do and should do are substantially different from the perceptions ten years ago. Furthermore, there has never been universal consensus on job roles in IS.

While familiar job titles have been taking on unfamiliar roles, many new IS-related job titles have been emerging with roles that are only vaguely understood. Chief Information Officer, IS Executive, Knowledge Engineer, Information Centre Analyst, and DSS Analyst are some of these emerging titles and moles. It would take a considerable effort to arrive at some clarity on all these titles and roles, however, we will spend time considering the top manager in IS only. This manager has been called many things but, sticking to job titles, we have seen the following: IS Manager, Chief Information Officer, and IS Executive. While some may be able to distinguish different roles for these different titles, I confess that I cannot.

The IS Manager/IS Executive/CIO is responsible mainly for:

- recommending hardware and software options;

- making the IS investment pay: 
- facilitating the provision of information services;

- providing access to corporate and external data;

- providing communication networks;

- suggesting information policy;

- aiding corporate planning;

- providing continuing education in information systems;

- identifying and transferring appropriate information technology; and

- acquiring and keeping quality IS staff.

Rockart (1982) suggests that the Chief Information Officer has the critical success factors; that is, the limited number of areas where 'things must go right', shown in Figure 1.

Service

Two-way communications with

Key users

Top management

\section{Information systems human resources}

He must be 'technically literate, managerially competent'.

He must retain the best of his COBOL people despite newer technology.

He must recognize that the key is quality people.

\section{Repositioning of information systems}

Technically

Organizationally

Psychologically

(Based on John F.Rockart [1982]).

Figure 1 Critical success factors of the IS executive

Shown in Figure 1 are generic critical success factors. Actual CSF's for the IS Executive may differ from case to case as a result of the stage of IS development of the organisation, the recent history of IS, the corporate culture, and financial factors.

The essence of the IS Manager/IS Executive/CIO is captured in the following profile:

' $I$ ' $d$ advise that the CIO concentrate on a few key points.

- Have the highest quality staff. Develop and challenge them and set an example of the highest integrity.

- Know your company - be an integral part of it and develop excellent personal relationships at all levels.

- Focus on business and business change. Keep windows to the outside world open, and don't be arrogant or you'll be blindsided.

- Emphasize technology leadership rather than control. Recognize trends and get out in front of them, but keep looking over your shoulder; the waves will still come.

- Understand technological issues and complexities - but not their intimate details - so you can make an intellectual contribution to the company's strategic objectives.

- Thrive on change, take managed risks, and tolerate continued ambiguity.

- Finally, don't lose your sense of humor or compassion. You'll need them both' (Mather, 1986).
These views on IS managers are not definitive and may not suit everyone's management style, but they do provide a flavour of what the job is all about and one thing is for sure; it is a far cry from the traditional DP manager role.

\section{Common threads}

A review of the above comments will show that the similarities between IRM and HRM are striking.

1. Both have to do with the management of a key corporate resource; in one case people and, in the other, information.

2. Both require a strategic vision, a strategy and a plan and must implement that plan efficiently and effectively.

3. Both the Manpower Plan and the Information Systems Plan are key components of the overall Business Plan and all three are interdependent.

4. Both have very similar components:

- Applications/activities

- Tools/methodologies

- People

- Organization

- Software

- Hardware

- Data

5. Both provide strategic services to their host organisations.

6. Both are experiencing changing roles which are increasing their importance to their organizations. The details of this for IS have been spelt out. For HRM one has only to think of industrial relations and manpower planning in a time of skills shortages, emigration and an educationally disadvantaged workforce.

7. Both have key roles to play in education and training.

\section{Some information challenges for HR}

From the preceding discussion it is clear that every person in an organization needs information. What has not been stressed thus far is that IS needs HR support also. In order to make this need clear we need to trace a little IS history. IS developments can be reviewed as three stages.

\section{Humanizing of IS}

\section{Stage 1: Technocrats' paradise}

Since time immemorial IS has been a haven for introverts and technocrats. In the early days of computers a high degree of technical skill was necessary to get anything at all done. The early programmers revelled in the challenge. They spent their days and nights conversing with machines which mostly behaved predictably if one knew what one was doing. It was an extremely satisfying intellectual activity. They rarely had to deal with unpredictable, unreliable human beings who regarded them with respect and kept a safe distance. There was little accountability since no one, let alone their managers, understood what they were doing.

This was the age of unfettered job satisfaction, independence, high rewards, and the unstinting respect of peers, employers'and society at large. 


\section{Stage 2: The first contact with people}

A decade or two ago this technical paradise began to change. Management still did not fully understand data processing and computers but they did understand that it was becoming increasingly expensive and that, if one did not somehow plan, organise and control IS, the result could be unpleasant, if not fatal. From an IS perspective the professionals found that they had to interact with people. Managers wanted not only results but they wanted them on time and on cost. They were not successful in this fanciful endeavour very often and it was a nuisance. Then the people who had thus far gratefully accepted the systems that IS built for them began to insist on consultation. The age of participation had amived. The walls of technocracy had been irrevocably breached. The theorists at business schools and other institutions were preaching heresies like user participation, the system belongs to the user, project management is people management, steering committees should prioritise systems development - not IS. COBOL programmers were still protected from these revelations but systems analysts and DP managers were reeling. The fact that the tidal wave of new information technology (IT) was rising constituted an attack from the rear for the technocrats for they had always prided themselves on knowing almost everything about IS and this had long since become impossible.

This was the age of user and management dissatisfaction, dawning human awareness in some areas of IS, accountability and the unsetuling realization in IS that their technology was getting away from them.

\section{Stage 3: The PC age}

The arrival of the personal computer (PC) in the early 1980 's changed the IS world completely and forever although this realisation is only starting to dawn on the more dyed-in-the-wool technocrats. End users saw escape from development backlogs and the dead hand of DP although in many cases this tumed out to be a mirage. They actually began to do things on their PC's without referring to IS. IS professionals were confronted with a $\mathrm{PC}$ invasion, an irresistable shift of control towards end-user computing and bewildering changes in their organizational roles. The business school exhortations had by now shifted to the strategic impact of IS (McFarlan \& McKenney, 1983), its use as a competitive weapon (Porter, 1985), the recognition of the PC as a powerful workstation for management, and expert systems. Ill-defined roles proliferated: knowledge engineers, information centre analysts, business analysts, information engineers and the IS Executive. The top IS manager had now to be a businessman and be able to operate at the strategic management level in many organisations.

This is the age of role proliferation and change, power shifts, anxieties about new, different and fast-changing technologies, strategic management demands, human resource management and organization design.

\section{The teching of HR}

While all this was happening in IRM, HRM was undergoing a few changes of its own. Recruitment and selection had become a key activity in the face of skills shortages and emigration; education and training was being used to try to bring all population groups into the business world; HRM found itself in the frontline of the industrial relations pressure cooker; and the management of change assumed a new significance in the South African socio-political environment. In addition, however, information technology had been moving into the HR area in the form of PC's, personnel databases, fringe benefits and taxation packages, manpower planning and sundry other decision-support systems. In the same way that the technocrats found themselves increasingly embroiled in people and organizational issues, the HR people found themselves increasingly having to come to terms with information tecnnology and related issues. For many of them it was an equally uncomfortable experience. In many ways IRM and HRM have converged.

\section{IS challenges for HR}

In the same way that HR can expect their IS colleagues to assist them with technological issues, they have a duty to assist with HR issues. How, specifically, can HR assist and why should they? The areas where most IS people feel inadequate today include the following insofar as they affect IS people:

- Career planning

- Staff development right up to IS Executive level

- Aspects of education and training

- Organization design

- Management of change especially in implementation and technology transfer

- Manpower planning

— Industrial relations (some IS shops are unionising)

- Social effects of IT

- Workplace effects of IT

- User and management relations

- Reward packages

- Experts that look like computers

Why should HR assist their IS colleagues? The answer is simple. For the reasons mentioned at the beginning of this article, it is becoming increasingly difficult for organisations (and this means not only business organisations) to survive and prosper in today's turbulent environment. The successful organizations can only be those that effectively blend the hi tech with the hi touch. A good formula for the future is excellence in the key functional and strategic areas and the ability to blend these.

\section{Conclusion}

This rather free-ranging article has looked at the IS function and the information resource that it manages. We found that there are many similarities between IRM and HRM and traced the convergence of the two disciplines. The concluding point was that the bottom line will depend in future on strength in both IRM and HRM and the ability of management to derive synergy from them.

The last word goes to John F. Kennedy who said that, 'Man is still the most extraordinary computer of all'. 


\section{References}

Canning, R.G. (Ed.) 1983. How work will change user experiences. EDP Analyzer, Vol. 21, No. 4.

Duffy, N. M. \& Assad, M.G. 1989. Information management: Strategy formulation and implementation. Cape Town: Oxford University Press, 540p.

Mather, P. 1986. Mather Profiled: MIS keystones. SIM Network, August/September, 5.
McFarlan, F.W. \& McKenney, J.L. 1983. Corporate information systems management: The issues facing senior executives. Homewood, Illinois: Richard D. Irwin.

Porter, M.E. 1985. Competitive advantage. New York: The Free Press.

Rockarh. J.F. 1982. The changing role of the information systems executive: A critical success factors perspective. Sloan Management Review, Fall, 3-13. 